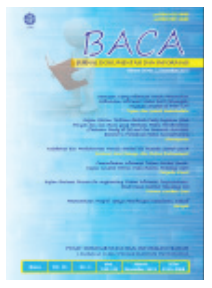

\title{
KINERJA PERPUSTAKAAN PDII-LIPI SERPONG BERDASARKAN INDEKS KEPUASAN PENGGUNA, RANKING ASPEK LAYANAN, DAN PERBANDINGAN DENGAN LEMBAGA SEJENIS
}

\author{
Yaniasih $^{1 *}$; Tupan ${ }^{2} ;$ Ambar Yoganingrum ${ }^{3}$; Rulina Rachmawati ${ }^{4}$ \\ 1,2,3,4 Pusat Dokumentasi dan Informasi Ilmiah - LIPI \\ *Korespondensi: yani.asih@gmail.com
}

Diajukan: 5-3-2016; Direview: 15-6-2016; Diterima: 10-8-2016; Direvisi: 2-9-2016

\begin{abstract}
PDII had a unit in Puspiptek Serpong called UPJ PDII Serpong in charge of providing access to scientific information. To improve its service quality, it was necessary to evaluate user's perception on provided services and compared it to the other library services in Puspiptek area. Evaluation was done on user's satisfaction in the aspects of content, personnel, facilities, and price. Data were collected using questionnaires in the form of Google Form. Questionnaires were distributed to researchers in Puspiptek Serpong area, which were from LIPI, BATAN, and BPPT. Data obtained were analyzed using statistic descriptive method. Performance aspects were analyzed using Shannon Entropy to get the weight and the rank performances. The Performance of UPJ PDII Serpong compared tothe similar institutions using the Wilcoxon Match Pairs Test. Result showed that the customer satisfaction consist of content availability, servicespeed, price, librarian's attitude, facilities, suitability of the content had an index of satisfaction with the value of B (Good). The librarian's attitude had the highest performance, followed by the availability and suitability of content, service speed, facilities, and price. The performance of UPJ PDII Serpong superior in all aspects compared to BPPT and BATAN library performance.
\end{abstract}

\begin{abstract}
ABSTRAK
Unit Pelaksana Jasa (UPJ) PDII Serpong merupakan salah satu unit perpustakaan di lingkungan Puspiptek Serpong yang bertugas menyediakan akses informasi ilmiah. Untuk meningkatkan kualitas layanan UPJ PDII Serpong perlu dilakukan evaluasi persepsi pengguna terhadap layanan yang diberikan dan perbandingan layanan perpustakaan lain di lingkungan Puspiptek. Evaluasi dilakukan terhadap kepuasan pengguna dalam aspek konten, petugas, fasilitas dan harga. Data dikumpulkan menggunakan kuesioner dalam bentuk Google Form yang disebarkan kepada peneliti di Kawasan Puspiptek Serpong, yaitu dari LIPI, BATAN dan BPPT. Data yang diperoleh dianalisis secara statistik deskriptif. Bobot dan ranking aspek kinerja UPJ PDII Serpong dianalisis menggunakan Shannon Entropy. Kinerja UPJ PDII-LIPI Serpong dibandingkan dengan lembaga sejenis menggunakan Wilcoxon Match Pairs Test. Hasil menunjukkan bahwa kepuasan pelanggan terhadap kinerja UPJ PDII Serpong meliputi ketersediaan konten, kecepatan layanan, harga, sikap petugas, fasilitas, kesesuaian konten memiliki indeks kepuasan dengan nilai B (Baik). Sikap petugas memiliki bobot kinerja tertinggi, kemudian berturut-turut aspek ketersediaan dan kesesuaian konten, kecepatan layanan, fasilitas dan harga. Kinerja UPJ PDII Serpong unggul di semua aspek dibandingkan dengan Perpustakaan BPPT ataupun Perpustakaan BATAN.
\end{abstract}

Keywords: Library performance; Shannon entropy; User's satisfaction index; Wilcoxon match pairs test 


\section{PENDAHULUAN}

Pusat Penelitian Ilmu Pengetahuan dan Teknologi (Puspiptek) Serpong merupakan satu kawasan riset terpadu yang didirikan sejak tahun 1976. Pendirian kawasan ini bertujuan untuk menyediakan sarana riset yang terarah dan terintegrasi untuk meningkatkan peranan penelitian, ilmu pengetahuan, dan teknologi dalam pembangunan nasional. Di kawasan ini telah beroperasi 47 laboratorium dan berbagai sarana teknis dalam koordinasi Lembaga Ilmu Pengetahuan Indonesia (LIPI), Badan Pengkajian dan Penerapan Teknologi (BPPT), Badan Tenaga Nuklir Nasional (BATAN), serta laboratorium Sarana Pengendalian Dampak Lingkungan Kementerian Lingkungan Hidup dan Kehutanan (Sarpedal KLHK) dan Pusdiklat Lingkungan (Kementerian Riset dan Teknologi RI, 2012).

Pada tahun 2014, pembangunan Puspiptek semakin diarahkan pada pembentukan science and techno park (STP). STP bertujuan untuk meningkatkan kolaborasi antar-universitas, lembaga penelitian dan pengembangan, serta industri. Di dalam STP, peran pusat informasi yang bertugas untuk menyediakan layanan konsultasi dan akses informasi dalam menunjang alih teknologi dari peneliti dan lembaga penelitian kepada masyarakat menjadi sangat penting (Kementerian Riset dan Teknologi RI, 2014). Peran ini dapat dilakukan dengan meningkatkan kualitas layanan perpustakaan di Kawasan Puspiptek Serpong yang saat ini terdiri dari tiga unit perpustakaan, yaitu Unit Pelaksana Jasa Pusat Dokumentasi dan Informasi Ilmiah - Lembaga Ilmu Pengetahuan Indonesia (UPJ PDII-LIPI) Serpong, Perpustakaan BATAN, dan Perpustakaan BPPT.

UPJ PDII-LIPI Serpong (selanjutnya disebut UPJ PDII Serpong) beroperasi pertama kali pada tahun 1993. Pada awalnya, unit ini menjadi andalan bagi peneliti dan industri di kawasan Puspiptek untuk memperoleh informasi ilmiah. Namun dengan semakin mudahnya akses informasi online, tantangan unit ini semakin besar sehingga perlu dilakukan evaluasi kinerja khususnya berdasarkan persepsi pengguna. Evaluasi dilakukan dengan mengukur kepuasan pengguna terhadap beberapa aspek layanan, yaitu konten, petugas, fasilitas, dan harga. Selain itu, pengguna juga diminta untuk membandingkan kualitas layanan UPJ PDII dengan perpustakaan lain di Puspiptek. Hal ini penting untuk mengetahui bagaimana kualitas UPJ PDII Serpong di antara lembaga yang sejenis.

Permasalahan penelitian ini adalah bagaimana kinerja UPJ PDII Serpong berdasarkan pengukuran indeks kepuasan masyarakat dan perbandingan dengan layanan sejenis di Kawasan Puspiptek Serpong. Adapun pertanyaan penelitian ini, yaitu: (a) bagaimana kinerja UPJ PDII Serpong?; (b) bagaimana bobot dan ranking kinerja pada beberapa aspek layanan?; dan (c) apakah kinerja UPJ PDII Serpong lebih baik dibandingkan dengan perpustakaan BPPT dan BATAN di Kawasan Puspiptek Serpong? Tujuan umum penelitian, yaitu mengukur kinerja perpustakaan di UPJ PDII Serpong, dan tujuan khususnya, yaitu: (a) mengetahui kepuasan pengguna terhadap layanan yang diberikan oleh UPJ PDII Serpong; (b) mengukur bobot dan ranking aspek layanan UPJ PDII Serpong; dan (c) membandingkan kinerja beberapa layanan perpustakaan Kawasan Puspiptek Serpong.

\section{TINJAUAN PUSTAKA}

\subsection{Kinerja Perpustakaan}

Pengukuran kinerja perpustakaan merupakan kegiatan penting untuk meningkatkan kualitas lembaga. Ada beberapa indikator kinerja perpustakaan. Mulai dari pengukuran efektivitas penggunaan sumber daya yang dimiliki sampai pengukuran dampak dan manfaat perpustakaan yang umumnya lebih sulit untuk diukur secara kuantitatif (Brophy, 2006). Pengukuran kinerja perpustakaan di Indonesia umumnya mengacu pada indikator kinerja ISO 11620-1998. Ada 29 indikator dalam standar ini. Setiap perpustakaan dapat memilih indikator mana yang akan digunakan sesuai dengan visi dan fungsi perpustakaan tersebut (Purnomowati, 2000).

PDII pada tahun 2007 telah menyusun buku yang menetapkan 15 indikator yang digunakan untuk mengukur kinerja perpustakaan. Lima belas indikator tersebut, yaitu: (1) median waktu pengadaan dokumen; (2) median waktu pengolahan dokumen; (3) ketersediaan judul; (4) penggunaan di perpustakaan perkapita; (5) tingkat penggunaan dokumen; (6) median waktu temu kembali dokumen; (7) perputaran koleksi; (8) peminjaman perkapita; (9) ketersediaan fasilitas; (10) tingkat penggunaan fasilitas; (11) 
tingkat penggunaan tempat duduk; (12) ketersediaan otomasi; (13) persentasi populasi target yang dicapai; (14) kunjungan perpustakaan perkapita; dan (15) kepuasan pengguna (Pusat Dokumentasi dan Informasi Ilmiah (PDII), 2007). Sebagian besar indikator yang dipilih terkait dengan efektivitas sumber daya. Hanya satu indikator yang mengukur dari sisi pengguna yaitu tingkat kepuasannya.

Tingkat kepuasan pengguna sudah banyak dilakukan namun jarang yang langsung memberikan penilaian kualitas kinerja perpustakaan apakah baik atau buruk berdasarkan nilai kepuasan tersebut. Penghitungan kepuasan pengguna dalam ISO 11620-1998 juga tidak memberikan nilai kualitas kinerja. Oleh karena itu, pengukuran kepuasan pengguna perpustakaan dapat dimodifikasi dengan mengadopsi metode pengukuran indeks kepuasan masyarakat unit layanan pemerintah (Kemenpan, 2004). Metode ini memberikan penilaian kualitas kinerja lembaga baik atau buruk berdasarkan nilai indeks kepuasan penggunanya.

\subsection{Kepuasan Pengguna}

Definisi kepuasan dalam layanan produk maupun jasa umumnya mengarah pada pemenuhan ekspektasi pengguna. Kepuasan didefinisikan sebagai sebuah standar atau upaya pemenuhan harapan pengguna (Grigoroudis \& Siskos, 2009). Adapun kepuasan bagi pengguna adalah tingkat perasaan seseorang setelah membandingkan kinerja yang diharapkan dengan yang diperoleh. Harapan pengguna terhadap produk atau jasa merupakan standar kualitas yang diinginkan, sedangkan kinerja yang diperoleh adalah kondisi dari produk dan jasa tersebut (Supranto, 2011; Tjiptono \& Chandra, 2011).

Kepuasan pelanggan menjadi konsep penting bagi bisnis maupun layanan publik (Kotler \& Lee, 2015). Pengukuran tingkat kepuasan diperlukan untuk memahami, menganalisis dan mengevaluasi perkembangan organisasi. Pengukuran kepuasan juga bermanfaat untuk mengidentifikasi cara untuk menarik pelanggan baru, mempertahankan pelanggan lama dan meningkatkan reputasi lembaga (Transportation Research Board, 1999). Tanpa pengukuran, organisasi tidak akan bisa mengetahui kualitas produknya dan tidak bisa mengelola produk tersebut. Setelah dievaluasi, organisasi diharapkan dapat memenuhi kebutuhan pelanggan secara lebih baik sehingga pelanggan tersebut akan loyal dengan produk dan jasa yang ditawarkan (Hill, Self, \& Roche, 2002).

Pengukuran tingkat kepuasan dapat dilakukan dengan metode kajian kualitatif dan kuantitatif. Kualitatif dilakukan dengan interview mendalam dan grup diskusi terfokus. Adapun metode kuantitatif dilakukan dengan survei menggunakan kuesioner baik bertemu langsung, menggunakan teknologi internet maupun telepon (Hill et al., 2002). Masingmasing metode tersebut memiliki kelebihan dan kekurangan. Kajian ini menggunakan metode kuantitatif survei menggunakan email. Metode survei direkomendasikan dalam melaksanakan pengukuran indeks kepuasan masyarakat terhadap layanan publik di Indonesia oleh Kementerian Pendayagunaan Aparatur Negara RI (Kemenpan, 2004). Kelebihan metode ini adalah biaya yang lebih murah, bisa menjangkau wilayah yang luas, tidak ada tekanan bagi responden untuk menjawab serta tidak ada bias dari pewawancara. Adapun kekurangan metode survei melalui email antara lain respon yang rendah dan lambat serta pertanyaan harus dibuat sederhana supaya tidak bias (Grigoroudis \& Siskos, 2009).

Kajian mengenai kepuasan pemustaka terhadap layanan perpustakaan sudah banyak dilakukan di Indonesia. Kajian tersebut antara lain untuk mengetahui faktor-faktor yang menentukan kepuasan serta evaluasi kepuasan terhadap layanan perpustakaan. Kajian yang dilakukan oleh Nurkertamanda dan Wirawan (2009) menunjukkan atribut penting dalam peningkatan kepuasan pengguna perpustakaan adalah layanan petugas (sikap dan keterampilan), ketersediaan literatur elektronik, fasilitas ruangan yang nyaman, koleksi yang terawat dan biaya layanan yang terjangkau. Hal yang sama juga dihasilkan dalam penelitian Firma dan Rahmah (2012) bahwa faktor yang berpengaruh terhadap kepuasan pengguna perpustakaan adalah sumber daya manusia, koleksi, sarana dan prasarana. Sarana, koleksi, layanan staf dan harga dipilih dalam kajian makalah ini sebagai faktor yang dievaluasi dalam layanan perpustakaan di PDII Serpong. Adapun penelitian mengenai evaluasi kualitas layanan perpustakaan dilakukan oleh Saleh, Sumarni, dan Safitri (2014) terhadap perpustakaan Badan Standarisasi Nasional dan Wijaya (2015) terhadap 
perpustakaan Umum Daerah Tabanan.

\section{METODE}

\subsection{Pengumpulan Data}

Data dikumpulkan menggunakan kuesioner. Penyusunan kuesioner dilakukan mengunakan produk Google Form dan penyebaran dilakukan secara online. Pertanyaan kuesioner terdiri dari dua jenis pengukuran, yaitu:

1) Skala

Pada setiap pernyataan, responden diminta memilih 1 (satu) jawaban yang paling sesuai. Jawaban responden diukur dengan menggunakan skala Likert. Skala Likert yang digunakan memiliki rentang pengukuran sebagai berikut:

- Skala 1 = Sangat Tidak Setuju

- Skala 2 = Tidak Setuju

- Skala $3=$ Netral

- Skala $4=$ Setuju

- Skala 5 = Sangat Setuju

Skala Likert diterapkan untuk mengukur kinerja UPJ PDII Serpong. Aspek yang diukur adalah ketersediaan konten, kesesuaian konten, kecepatan layanan, kesesuaian harga, kompetensi petugas dan ketersediaan fasilitas (sarana/ prasarana).

2) Ranking

Pada setiap pertanyaan, responden diminta untuk meranking lembaga yang telah disediakan. Cara ini digunakan untuk mengukur perbandingan kinerja UPJ Serpong dengan lembaga lain yang sejenis.

\subsection{Populasi dan sampel}

Responden adalah pegawai yang memiliki jabatan fungsional peneliti di Kawasan Puspiptek Serpong. Mereka terdiri dari peneliti LIPI, BATAN, dan BPPT. Jumah peneliti yang dikirim kuesioner adalah 293 orang dari jumlah populasi sebanyak 583. Data jumlah peneliti diperoleh dari pusbindiklat LIPI dan dari masing-masing Pusat Penelitian. Adapun data alamat email peneliti diperoleh dari jurnal-jurnal yang diterbitkan oleh satuan kerja di kawasan PUSPIPTEK Serpong, website intra LIPI, dan pencarian melalui internet. Tidak semua populasi peneliti dikirim kuesioner karena kesulitan dalam memperoleh alamat email dan beberapa alamat email yang sudah diperoleh ternyata tidak valid.

\subsection{Analisis Data}

Cara analisis kuesioner pada penelitian ini, sebagai berikut.

1) Statistik deskriptif, yaitu frekuensi dan persentase untuk identifikasi kebutuhan informasi responden dan pengukuran kinerja. Proses analisis menggunakan aplikasi Ms. Excel.

2) Analisis indeks kepuasan mengadopsi metode pengukuran indeks kepuasan masyarakat unit layanan pemerintah (KEMENPAN, 2004). Penghitungan menggunakan Microsoft Excel. Rumus yang digunakan adalah sebagai berikut:

$$
\begin{aligned}
& \text { Rataan skor kepuasan }=\frac{\text { Jumlah skor kepuasan }}{\text { Jumlah responden }} \\
& \text { Indeks kepuasan }=\frac{\text { Rataan } \text { skor kepuasan }}{\text { Skor } \text { maksimal }} \times 100
\end{aligned}
$$

Konversi dari nilai kepuasan menjadi nilai mutu dan kinerja mengikuti Tabel 1. 
Tabel 1. Standar Nilai Kepuasan, Mutu Layanan Dan Kinerja Pelayanan

\begin{tabular}{|c|c|c|}
\hline Indeks Kepuasan & Mutu Pelayanan & Kinerja Unit Pelayanan \\
\hline $25-43,75$ & D & Tidak baik \\
\hline $43,76-62,50$ & C & Kurang baik \\
\hline $62,51-81,25$ & B & Baik \\
\hline $81,26-100,00$ & A & Sangat baik \\
\hline
\end{tabular}

3) Analisis Shannon Entropy untuk pengukuran bobot dan menentukan urutan nilai aspek kinerja UPJ PDII Serpong. Proses analisis menggunakan aplikasi Ms. Excel. Tahapan dalam analisis Shannon Entropy adalah seperti terlihat pada gambar 1.

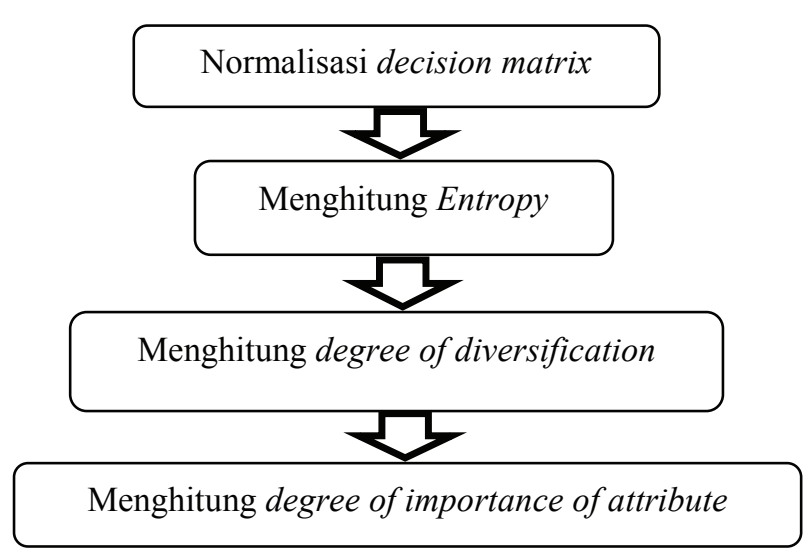

Gambar 1. Tahapan shannon entropy

4) Wilcoxon Match Pairs Test (Wilcoxon Signed Rank Test) untuk membandingkan UPJ PDII Serpong dengan lembaga sejenis. Ini merupakan salah satu teknik pengujian hipotesis komparatif sampel berpasangan, dengan data berbentuk ordinal (Sugiyono, 2015). Sampel dikatakan berpasangan karena menggunakan sampel yang sama untuk menilai dua buah lembaga. Aspek yang dibandingkan ada 4 (empat), yaitu:

- lembaga yang menyediakan konten informasi paling sesuai dengan kebutuhan;

- lembaga yang memberikan harga layanan paling baik;

- lembaga yang memberikan layanan paling cepat;

- lembaga yang menyediakan fasilitas paling baik.

Penilaian dilakukan secara berpasangan, yaitu UPJ PDII Serpong dibandingkan dengan perpustakaan BPPT dan UPJ PDII Serpong dibandingkan dengan perpustakaan BATAN. Penghitungan menggunakan aplikasi SPSS 20.

\section{HASIL DAN PEMBAHASAN}

\subsection{Kepuasan Pelanggan}

Kinerja UPJ PDII Serpong diukur dengan cara mengukur kepuasan pelanggan. Kepuasan terhadap jasa secara umum dipengaruhi oleh beberapa aspek seperti petugas, produk, layanan, kredibilitas dan akses terhadap jasa tersebut (Grigoroudis \& Siskos, 2009). Beberapa kajian mengenai kepuasan terhadap jasa perpustakaan menunjukan beberapa aspek yang paling berpengaruh adalah petugas, koleksi, fasilitas dan biaya layanan. Kajian ini mengukur keempat aspek tersebut. Khusus aspek koleksi dibagi menjadi ketersediaan dan kesesuaian konten.

Hasil kuisioner memperlihatkan seluruh aspek memiliki indek kepuasan dengan nilai mutu B (Tabel 2). Penilaian indeks, nilai mutu dan kinerja mengacu pada penilaian kepuasan menurut MenPAN. Nilai indeks paling tinggi adalah sikap petugas dengan kepuasan 78,52 dan nilai paling rendah adalah aspek harga sebesar 66,67. Adapun aspek 
lainnya, yaitu kesesuaian dan ketersediaan konten mendapat nilai 71,21 dan 69,63; fasilitas mendapat nilai 70,63 serta kecepatan layanan mendapat nilai 68,18 . Seluruh nilai indeks kepuasan ini menunjukan kinerja layanan adalah baik. Indeks kepuasan total aspek yang juga menunjukan mutu dan kinerja unit layanan UPJ PDII Serpong adalah 72,22 yang bernilai mutu B dan masuk kinerja layanan baik.

Tabel 2. Urutan dan Nilai Kepuasan Terhadap Aspek Layanan

\begin{tabular}{|c|c|c|c|c|}
\hline Urutan & Unsur layanan & $\begin{array}{c}\text { Indeks } \\
\text { Kepuasan } \\
\text { Aspek }\end{array}$ & $\begin{array}{c}\text { Mutu } \\
\text { Layanan }\end{array}$ & $\begin{array}{c}\text { Kinerja } \\
\text { Layanan }\end{array}$ \\
\hline 1 & Sikap petugas & 78.52 & B & Baik \\
\hline 2 & Kesesuaian konten & 71.21 & B & Baik \\
\hline 3 & Fasilitas & 70.63 & B & Baik \\
\hline 4 & Ketersedian konten & 69.63 & B & Baik \\
\hline 5 & Kecepatan layanan & 68.18 & B & Baik \\
\hline 6 & Harga & 66.67 & B & Baik \\
\hline
\end{tabular}

Menganalisis skor kepuasan dari setiap aspek memperlihatkan sikap petugas mendapat rataan skor 2,41 yang merupakan skor paling tinggi. Skor ini mendekati nilai skor kepuasan maksimal 3. Aspek ketersediaan dan kesesuaian konten mempunyai rataan skor 2,14. Skor ini berada diatas nilai tengah (skor kepuasan sedang), yaitu 2. Adapun skor kecepatan layanan dan fasilitas mendekati nilai tengah skor kepuasan, yaitu 2,02 dan 2,05 . Satu-satunya aspek yang mendapat rataan skor kepuasan di bawah nilai tengah adalah harga dengan nilai rataan skor 1,91. Rataan skor semua aspek ditampilkan dalam Gambar 2.

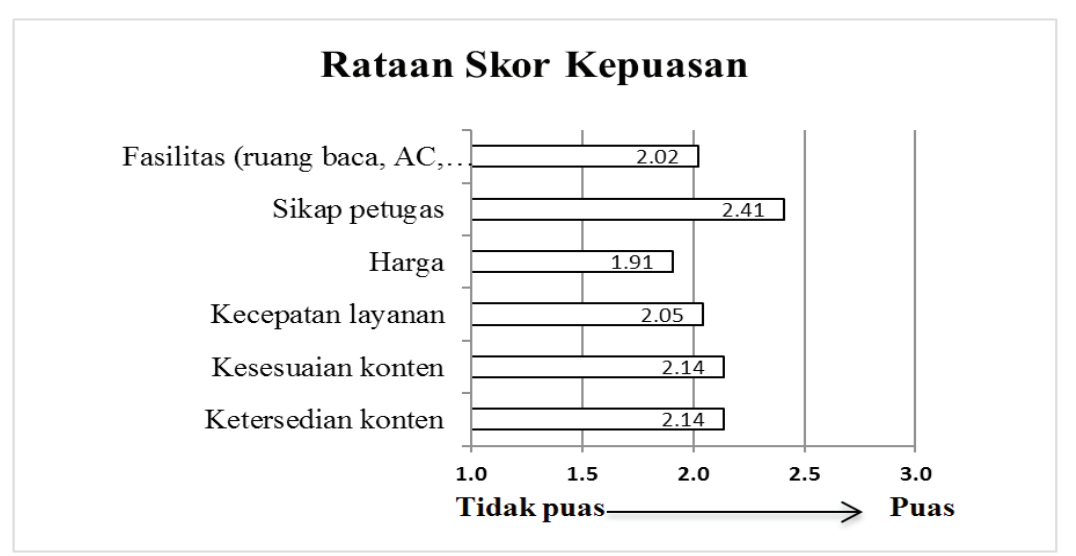

Gambar 2. Skor kepuasan terhadap layanan

\subsection{Kinerja Aspek Layanan}

Berdasarkan penghitungan dengan metoda Shannon Entropy, bobot kinerja setiap aspek disajikan dalam Tabel 3. Tabel 3 memperlihatkan bahwa sikap petugas merupakan aspek yang memiliki bobot tertinggi kemudian berturut-turut aspek ketersediaan dan kesesuaian konten, kecepatan layanan, fasilitas, dan harga. Urutan aspek merupakan urutan tingkat kepuasan pemustaka terhadap kinerja UPJ PDII Serpong. 
Tabel 3. Bobot dan Urutan Nilai Kinerja

\begin{tabular}{|c|c|c|}
\hline Aspek & Nilai Bobot & Urutan Aspek \\
\hline Ketersedian konten & 0,168 & 2 \\
\hline Kecepatan layanan & 0,164 & 3 \\
\hline Harga & 0,157 & 5 \\
\hline Sikap petugas & 0,181 & 1 \\
\hline Fasilitas & 0,163 & 4 \\
\hline Kesesuaian konten & 0,168 & 2 \\
\hline
\end{tabular}

Berdasarkan pada dua metode, kepuasan pelanggan terhadap pelayanan UPJ PDII Serpong memiliki urutan yang persis sama. Aspek sikap petugas di UPJ PDII Serpong yang mendapatkan skor tertinggi merupakan kondisi yang baik. Hal ini karena aspek petugas memberikan kontribusi terhadap empat dimensi karakter kepuasan layanan. Ada empat karakteristik dimensi layanan, yaitu reliability, responsiveness, assurance, dan emphaty. Dalam keempat dimensi ini sikap petugas memiliki peran contohnya dalam dimensi reliability, seperti kesungguhan petugas membantu pemustaka; dimensi responsiveness, seperti kesediaan petugas membantu; dimensi assurance, seperti kesopanan petugas dalam melayani dan kemampuan petugas menjawab pertanyaan; serta dimensi emphaty, seperti perhatian petugas terhadap pemustaka, petugas mementingkan kebutuhan pemustaka dan pemahaman petugas terhadap kebutuhan pemustaka (Saleh et al., 2014). Apabila pemustaka puas dengan sikap petugas, maka dapat dikatakan kebutuhan pemustaka terhadap keempat dimensi tersebut terlayani dengan baik.

Walaupun begitu, karena kajian ini tidak mengukur bobot kepentingan dari setiap aspek, secara khusus tidak dapat diukur apakah sikap petugas menjadi aspek yang paling penting bagi pemustaka di UPJ PDII Serpong dalam memperoleh kepuasan layanan. Namun bila melihat dari kajian sebelumnya yang pernah dilakukan, tiga hal yang paling penting menurut pemustaka dalam kepuasan layanan perpustakaan adalah kesegeraan pemberian layanan, kesediaan petugas membantu dan kesopanan petugas (Saleh et al., 2014). Menurut kajian tersebut, sikap petugas adalah aspek yang paling mempengaruhi kepuasan disamping waktu layanan.

Skor aspek kecepatan layanan sendiri dalam kajian ini mendapat skor mendekati sedang (nilai tengah). Skor yang tidak cukup tinggi ini mengingatkan pengelola unit layanan Serpong untuk semakin meningkatkan kecepatan layanan karena kecepatan layanan merupakan aspek yang paling penting bagi kepuasan pemustaka.

Satu aspek yang nilainya paling rendah dan berada di bawah nilai sedang adalah harga. Dalam dimensi layanan, harga masuk dalam dimensi emphaty, yaitu kewajaran tarif/ biaya layanan. Skor di bawah nilai tengah menunjukan pemustaka kurang puas bahkan mengarah pada tidak puas. Rincian jawaban responden memperlihatkan 5 responden tidak puas, 32 sedang, dan 5 puas. Jumlah responden yang tidak puas dan puas sama yaitu 5 dan sebagian besar $(76 \%)$ netral. Hal ini perlu mendapat perhatian serius dari pimpinan yang memiliki kewenangan anggaran bahwa perlu mengalokasikan dana untuk pengelolaan unit Serpong sehingga biaya pengelolaan tidak perlu mengambil dari jasa layanan. Apabila anggaran dari PDII dapat memenuhi kebutuhan pengelolaan unit Serpong, maka pengelola dapat memberikan tarif yang wajar dan bersaing bagi pemustaka. Harga yang memuaskan akan menaikan tingkat kepuasan pemustaka dan membuat seluruh aspek layanan memiliki skor kepuasan yang tinggi. 


\subsection{Perbandingan UPJ PDII Serpong dengan Lembaga Sejenis}

Pengukuran UPJ PDII Serpong dengan lembaga sejenis menggunakan Wilcoxon Match Pairs Test atau disebut Wilcoxon Signed Rank Test. Hipotesis yang dibangun adalah:

- Ho: UPJ PDII Serpong dan lembaga pembandingnya adalah sama;

- H1: UPJ PDII Serpong dan lembaga pembandingnya berbeda nyata.

Jika nilai probabilitas atau Asymp. Sig (2-tailed) lebih besar dari 0.05, maka Ho diterima dan H1 ditolak. Jika nilai Asymp. Sig (2-tailed) lebih kecil dari 0.05, maka Ho ditolak dan $\mathrm{H} 1$ diterima. Hasil perhitungan dapat dilihat pada Tabel 4 dan Tabel 5.

Tabel 4. Hasil Wilcoxon Match Pairs Test UPJ PDII Serpong dan Perpustakaan BPPT

\begin{tabular}{|c|c|c|c|c|}
\hline \multirow{2}{*}{$\begin{array}{c}\text { Aspek yang } \\
\text { dibandingkan }\end{array}$} & PDII Serpong & $\begin{array}{c}\text { Perpustakaan } \\
\text { BPPT }\end{array}$ & \multirow{2}{*}{ Z } & $\begin{array}{c}\text { Asymp. Sig } \\
\text { (2-tailed) }\end{array}$ \\
\cline { 2 - 5 } & positif & negatif & -3.604 & 0 \\
\hline Kesesuaian konten & positif & negatif & -2.3 & 0.02 \\
\hline Harga layanan & positif & negatif & -3.7 & 0 \\
\hline Kecepatan layanan & positif & negatif & -2.16 & 0.03 \\
\hline Fasilitas layanan & &
\end{tabular}

Tabel 5. Hasil Wilcoxon Match Pairs Test UPJ PDII Serpong dan Perpustakaan BATAN

\begin{tabular}{|c|c|c|c|c|}
\hline \multirow{2}{*}{$\begin{array}{c}\text { Aspek yang } \\
\text { dibandingkan }\end{array}$} & UPJ Serpong & $\begin{array}{c}\text { Perpustakaan } \\
\text { BATAN }\end{array}$ & \multirow{2}{*}{$\begin{array}{c}\text { Asymp.Sig } \\
\text { (2-tailed) }\end{array}$} \\
\cline { 2 - 3 } & positif & negatif & -2.12 & 0.03 \\
\hline Kesesuaian konten & positif & negatif & -2.38 & 0.01 \\
\hline Harga layanan & positif & negatif & -2.75 & 0.01 \\
\hline Kecepatan layanan & positif & negatif & -2.29 & 0.02 \\
\hline Fasilitas layanan & & &
\end{tabular}

Berdasarkan pada teknik Wilcoxon Match Pairs Test, terlihat nilai Asymp. Sig (2-tailed) lebih kecil dari 0.05. Angka tersebut menunjukkan ada perbedaan yang bermakna terhadap 4 aspek pada perbandingan antara UPJ PDII Serpong dengan Perpustakaan BPPT dan UPJ PDII Serpong dengan Perpustakaan BATAN. Nampak bahwa UPJ PDII Serpong unggul di semua aspek, baik terhadap Perpustakaan BPPT maupun Perpustakaan BATAN.

\section{KESIMPULAN}

Berdasarkan hasil kajian dan pembahasan yang telah dilakukan, dapat kesimpulan: (1) kinerja UPJ PDII Serpong dilihat dari segi kepuasan pelanggan yang meliputi ketersediaan konten, kecepatan layanan, harga, sikap petugas, fasilitas, kesesuaian konten memiliki indeks kepuasan dengan nilai $\mathrm{B}$; (2) dilihat dari bobot kinerja memperlihatkan bahwa sikap petugas merupakan aspek yang memiliki bobot tertinggi kemudian berturut-turut aspek ketersediaan dan kesesuaian konten, kecepatan layanan, fasilitas dan harga; dan (3) kinerja UPJ serpong UPJ PDII Serpong unggul di semua aspek yang meliputi penyediaankonten informasi paling sesuai dengan kebutuhan, memberikan harga layanan paling baik, memberikan layanan paling cepat, dan menyediakan fasilitas paling baik, apabila dibandingkan dengan Perpustakaan BPPT ataupun Perpustakaan BATAN. 


\section{DAFTAR PUSTAKA}

Brophy, P. 2006. Measuring Library Performance: Principles and Techniques (Vol. 95). London: Facet Publishing.

Firma, A. dan Rahmah, E. 2012. Faktor - Faktor yang Mempengaruhi Kepuasan Pemustaka di Perpustakaan Kopertis Wilayah X. Jurnal Ilmu Informasi Perpustakaan dan Kearsipan, $1(1), 110-115$.

Grigoroudis, E. dan Siskos, Y. 2009. Customer Satisfaction Evaluation: Methods for Measuring and Implementing Service Quality (F. S. Hillier, Ed.) (Vol. 7). New York: Springer.

Hill, N., Self, B. dan Roche, G. 2002. Customer Satisfaction Measurement for ISO 9000:2000. Oxford: Butterworth-Heinemann.

Kementerian Pendayagunaan Aparatur Negara/Kemenpan. 2004. Keputusan Menteri Pendayagunaan Aparatur Negara Nomor: KEP/25/M.PAN/2/2004 Tentang Pedoman Umum Penyusunan Indeks Kepuasan Masyarakat Unit Pelayanan Instansi Pemerintah. Jakarta.

Kementerian Riset dan Teknologi RI. 2012. "Selamat Datang di Puspiptek". (http://puspiptek. ristekdikti.go.id/media.php? module=halamanstatis\&id=4-pengantar.html, diakses 30 Maret 2016).

Kementerian Riset dan Teknologi RI. 2014. Panduan Pendirian Science and Technology Park (STP). Jakarta.

Kotler, P. dan Lee, N. 2015. Marketing in the Public Sector: A Roadmap for Improved Performance (Vol. 1). New Jersey: Wharton Schooll Publishing. doi:10.1017/CBO9781107415324.004.

Nurkertamanda, D. dan Wirawan, P.2009. Perpustakaan dengan Menggunakan Metodologi Libqual $+^{\mathrm{TM}}$ Dan Quality Function Deployment. JATI Undip, IV(2), 123-136.

Purnomowati, S. 2000. Mengukur Kinerja Perpustakaan. BACA: Jurnal Dokumentasi dan Informasi, $25(3-4), 61-67$.

Pusat Dokumentasi dan Informasi Ilmiah/PDII. 2007. Indikator Kinerja Perpustakaan Berdasarkan Standar Internasional. Jakarta: Lembaga Ilmu Pengetahuan Indonesia.

Saleh, A. R., Sumarni, E. dan Safitri, S. R. 2014. Kajian Analisis Kepuasan Pelanggan pada Layanan Perpustakaan Badan Standardisasi Nasional. Jurnal Pustakawan Indonesia, 13(2), 15-27.

Sugiyono. 2015. Statistik Nonparametris Untuk Penelitian. Bandung: Alfabeta.

Supranto, J. 2011. Pengukuran Tingkat Kepuasan Pelanggan Untuk Menaikkan Pangsa Pasar (2nd ed.). Jakarta: Rineka Cipta.

Tjiptono, F., \& Chandra, G. 2011. Service, Quality, \& Satisfaction (3rd ed.). Yogyakarta: Andi Offset.

Transportation Research Board. 1999. TCRP Report 47 A Handbook for Measuring Customer Satisfaction and Service Quality. Washington DC.

Wijaya, N. M.2015. Evaluasi Kepuasan Pengguna Terhadap Pelayanan di Perpustakaan Umum Daerah Tabanan. Jurnal Ilmiah D3 Perpustakaan, 1 (1), 1-6. 
